\title{
Involvement of Diamine Oxidase and Peroxidase in Insolubilization of the Extracellular Matrix: Implications for Pea Nodule Initiation by Rhizobium leguminosarum
}

\author{
J.-P. Wisniewski, ${ }^{1}$ E. A. Rathbun, ${ }^{1}$ J. P. Knox, ${ }^{2}$ and N. J. Brewin ${ }^{1}$ \\ ${ }^{1}$ Department of Genetics, John Innes Centre, NR4 7UH Norwich, U.K.; ${ }^{2}$ Centre for Plant Sciences, \\ University of Leeds, LS2 9JT, U.K. \\ Accepted 10 December 1999.
}

\begin{abstract}
Rhizobium leguminosarum colonizes host cells and tissues through infection threads, which are tubular in-growths of the plant cell wall. Monoclonal antibody MAC265 recognizes a plant matrix glycoprotein (MGP) associated with the lumen of these infection threads. This glycoprotein is also released in soluble form from the root tips of pea seedlings. In the presence of hydrogen peroxide, release of glycoprotein from root tips was not observed. Extractability from root tips was therefore used as the basis for investigating the peroxide-driven insolubilization of MGP and the possible involvement of two extracellular enzymes, peroxidase (POD) and diamine oxidase (DAO), was investigated. Release of MGP from root tips was enhanced by application of POD and DAO inhibitors (salicylhydroxamic acid and $o$-phenanthroline, respectively). Furthermore, release of MGP was inhibited by pretreatment of roots with putrescine (the substrate of DAO) and also by application of a partially purified extract of DAO from pea shoots. Following inoculation of pea roots with $R$. leguminosarum, elevated levels of DAO transcript were observed by reverse transcriptase-polymerase chain reaction (RT-PCR), but these then dropped to a low level from 4 to 10 days post inoculation, rising again in more mature nodules. In situ hybridization studies indicated that the bulk of the transcription was associated with the infected tissue in the center of the nodule. On the basis of these observations, we postulate that DAO may be involved in the peroxide-driven hardening of MGP in the lumen of infection threads and in the intercellular matrix.
\end{abstract}

Additional keywords: extensin, Pisum sativum, polyamine, $R$. leguminosarum bv. viciae, symbiosis.

Bacteria of the genus Rhizobium can stimulate leguminous plants to develop symbiotic root nodules, within which they differentiate to form endosymbiotic, nitrogen-fixing bacteroids. This nodulation process is the result of a highly complex plant-microbe interaction. In most temperate legumes, e.g., pea, clover, and alfalfa, rhizobia gain entry to host tissues

Corresponding author: N. J. Brewin; Telephone: +44 01603 452571; Fax: +44 01603 456844; E-mail: nick.brewin@bbsrc.ac.uk through a specialized trans-cellular tunnel, the infection thread. This is a tubular ingrowth, arising by invagination of the root hair cell wall or the root cortical cell wall. Rhizobia are subsequently released into host cells by endocytosis, thus colonizing the symbiosome compartment of the host cell endomembrane system (Brewin 1991). Throughout nodule development, the process of infection is established by a continual molecular dialogue between the specific Rhizobium strain and the host plant. This, apparently, results in the suppression of generalized plant defense mechanisms that might restrict the invasion of nonsymbiotic organisms (Long and Staskawicz 1993).

The penetration of bacteria into host root tissues is a key aspect of symbiotic development. The initiation of infection threads is apparently preceded by localized cell wall degradation (van Spronsen et al. 1994) and may be accompanied by modifications in cell wall peroxidase (POD) activities (Salzwedel and Dazzo 1993; Cook et al. 1995). However, not all infection threads result in successful invasions. In alfalfa, for example, many infection threads abort, even in compatible symbiotic interactions (Vasse et al. 1993). In pea, the extent of this host defense response is apparently aggravated in incompatible interactions (Perotto et al. 1994): lipopolysaccharidedefective mutants were shown to be only partially successful in colonizing the nodule tissue and were only released into a minority of host cells.

Within the infection threads, bacteria are normally surrounded by a matrix containing glycoproteins secreted by the plant (Bradley et al. 1988; VandenBosch et al. 1989) and rhizobial exopolysaccharides (Niehaus et al. 1993, 1998). With the use of a monoclonal antibody, MAC265, a 110-kDa plant glycoprotein was identified as a major component of the infection thread lumen (VandenBosch et al. 1989) and the intercellular matrix (Rae et al. 1991, 1992). Peptide sequencing of immunopurified matrix glycoprotein (MGP) has recently revealed that it is probably a dimeric form of a heavily glycosylated extensin (Brewin et al. 2000).

A possible role for MGP in the regulation of tissue and cell invasion by $R$. leguminosarum has been suggested by a number of recent observations with MAC265 antibody as a probe. Enhanced secretion of MGP by host cells was observed as an early response to R. leguminosarum infection in pea and Vicia 
spp. roots (Rae et al. 1991). Furthermore, in nodules induced by lipopolysaccharide-defective strains, abnormal and large intrusion structures were observed, revealing invading bacteria surrounded by abundant and apparently overproduced MGP (Perotto et al. 1994). In a parallel study, it was shown that when suspension cultures of soybean cells were challenged with a fungal elicitor, a structural protein recognized by MAC265 was insolubilized by peroxide-mediated oxidative cross-linking (Bradley et al. 1992). Cross-linking of cell wall proteins has subsequently been widely reported as a rapid response to plant pathogens both in vivo (Wojtaszek et al. 1995; Otte and Barz 1996) and in vitro (Wojtaszek et al. 1997).

In the present study, we investigate the possible role of MGP in the plant-mediated control of infection thread growth through peroxide-induced hardening of the intercellular matrix. Furthermore, we examine the possible role of pea diamine oxidase (DAO) as a potential source of hydrogen peroxide $\left(\mathrm{H}_{2} \mathrm{O}_{2}\right)$. This enzyme, which is involved in polyamine catabolism, oxidizes putrescine and cadaverine with the formation of the corresponding aldehyde, $\mathrm{H}_{2} \mathrm{O}_{2}$ and ammonia (Smith and Barker 1988). With the use of immunolocalization

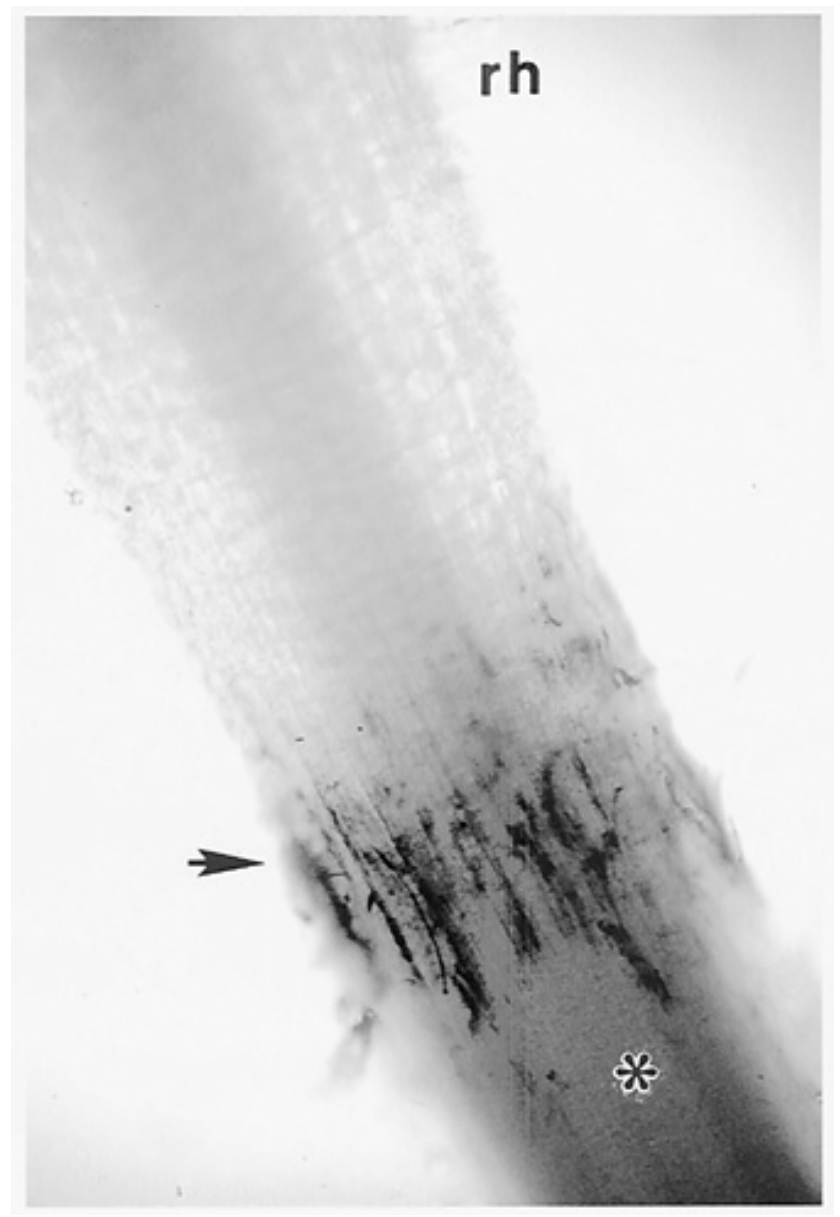

Fig. 1. Immunolocalization of matrix glycoprotein (MAC265 antigen) at the surface of a Vicia hirsuta root tip. Intact root tissue was incubated for 30 min with MAC265 and subsequently immunostained as for Western blotting (immunoblotting). Arrow, strong staining associated with surface cells on proximal end of the root cap $(*) . \mathrm{Rh}=$ root hair zone. Roots not incubated with MAC265 showed no staining (not shown). techniques, DAOs have been mostly found in the apoplast of mature tissues and it has been proposed that these enzymes have a special role in the localized production of $\mathrm{H}_{2} \mathrm{O}_{2}$ from polyamine substrates (Angelini et al. 1990). In turn, this $\mathrm{H}_{2} \mathrm{O}_{2}$ can be utilized by POD enzymes present in the apoplast, thus leading to the modulation of cell wall plasticity. The activity of DAO is modulated by various stress factors (Maccarrone et al. 1991, 1997), and a parallel increase in DAO and POD activities was demonstrated together with ligno-suberized depositions in wounded chick-pea stems (Angelini et al. 1990).

Because MGP is normally secreted from pea root tips, we have been able to develop an in vitro bioassay for its insolubilization by examining factors that reduce its secretion into the surrounding medium. We report that MGP is insolubilized in pea roots by a phenomenon that is dependent on $\mathrm{H}_{2} \mathrm{O}_{2}$ in a time-dependent manner. Using specific inhibitors, we show that the insolubilization of MGP at the root surface is driven by POD activity, and we provide evidence that DAO could provide $\mathrm{H}_{2} \mathrm{O}_{2}$ to accomplish this reaction.

\section{RESULTS}

\section{MGP insolubilization is induced by $\mathrm{H}_{2} \mathrm{O}_{2}$.}

Although MGP (MAC265 antigen) was first observed as a component of infection threads and intercellular spaces in the nodule parenchyma (Rae et al. 1991, 1992), a more convenient source of material is seedling root tips, where the antigen could be detected with MAC265 antibody in the proximal part of the root cap (Fig. 1). The release of MGP into an extraction buffer was monitored by the bioassay protocol illustrated in Figure 2. After sodium dodecyl sulfate-polyacrylamide gel electrophoresis (SDS-PAGE) and Western blotting (immunoblotting), MAC265 identified an antigen doublet around $110 \mathrm{kDa}$ as well as a band with a higher molecular mass (Fig. 3, lane C). The positions of these antigen bands were indistinguishable from those derived from nodule extracts (data not shown). Pretreatment of the root with $\mathrm{CaCl}_{2}$ $(0.2 \mathrm{M})$, oxalate $(20 \mathrm{mM})$ or EDTA $(0.1 \mathrm{M})$ increased the release of antigen from tips (Fig. 3, lanes D, B, and A, respectively), suggesting that MGP may be loosely bound to the root surface by calcium bridges and ionic bonds. In the case of

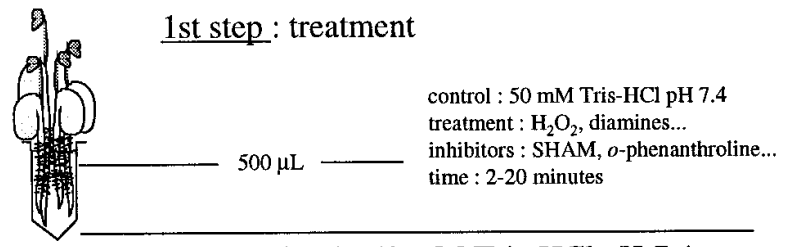

$2 \mathrm{x}$ washing in $50 \mathrm{mM}$ Tris- $\mathrm{HCl} \mathrm{pH} 7.4$

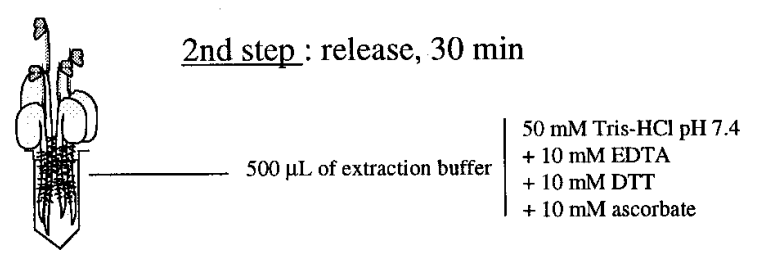

Fig. 2. Outline of bioassay used to analyze extractability of matrix glycoprotein (MGP) from pea root tip surface. Six 4-day-old seedlings were used in each experiment. 
$\mathrm{CaCl}_{2}$ pretreatment only, bands of lower molecular mass cross-reacting with MAC265 were also detected. On the other hand, $\mathrm{H}_{2} \mathrm{O}_{2}$ added to the Tris- $\mathrm{HCl}$ buffer induced a rapid reduction in the release of the MGP: this was detectable as soon as $2 \mathrm{~min}$ after contact with a $5 \mathrm{mM}$ solution (Fig. 4, lane B). The effect of $\mathrm{H}_{2} \mathrm{O}_{2}$ was dependent on time and concentration and was apparently specific for MGP, in that the release of chalcone synthase from pea roots was unaffected by peroxide treatments of less that 20 min duration. (This was detected by immunoblotting: data not shown.) However, while $\mathrm{H}_{2} \mathrm{O}_{2}$ blocked the release of MGP from root tips, immunoreactivity was still observed in situ at the surface of the roots (data not shown). Moreover, $\mathrm{H}_{2} \mathrm{O}_{2}$ showed no evidence of denaturing MAC265 antigen when applied to purified glycoprotein (data not shown). Thus, we conclude that application of $\mathrm{H}_{2} \mathrm{O}_{2}$ appeared to affect the extractability of MGP from root tips. The higher molecular mass antigen forms sometimes observed on Western blots presumably represent higher aggregation states of MGP: since their behavior is essentially similar to that of the $110-\mathrm{kDa}$ antigen, we have chosen to ignore them for the time being.

\section{DAO localization and activity in pea tissues.}

Monoclonal antibody LM4 recognizes the native (but not the glutaraldehyde-fixed) form of pea seedling DAO. With nonfixed tissue, DAO was localized by immunofluorescence to the regions of cell walls lining intercellular spaces of pea epicotyl (Fig. 5A). DAO was also localized in cell walls and intercellular spaces near the apex of nodules, both in the nodule cortex and in the invasion zone (Fig. 5B). Thus, the extracellular localization of DAO corresponded closely to that of MAC265 antigen (data not shown).

Using an enzyme assay, we also quantified the specific activity of DAO in different pea tissues (Table 1). Although the highest level of activity was found in epicotyl extracts, a substantial activity was quantified in nodule extracts.

\section{Polyamine-induced MGP insolubilization.}

When putrescine, the preferred substrate for DAO, was applied to pea roots for $5 \mathrm{~min}$, it caused a total disappearance of MGP from the Western blot of root exudate (Fig. 6, lane B). On the other hand, histamine and spermine, which are less effective as substrates for pea DAO (Medda et al. 1995), induced a partial or no disappearance of MGP (Fig. 6, lanes C

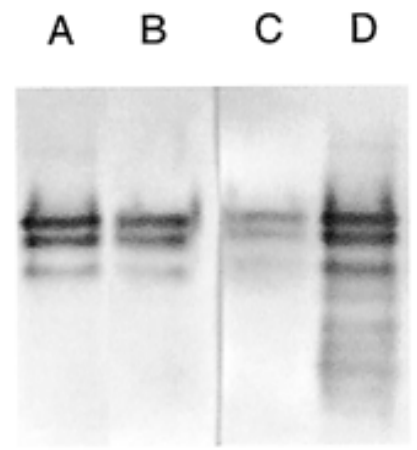

Fig. 3. Western blot (immunoblot) probed with MAC265, showing release of matrix glycoprotein (MGP) from root exudate following various treatments: A, 0.1 M EDTA; B, $20 \mathrm{mM}$ oxalate; $\mathbf{C}$, control treatment in $50 \mathrm{mM}$ Tris-HCl buffer pH 7.4; D, $0.2 \mathrm{M} \mathrm{CaCl}_{2}$. and D). With extracts from pea epicotyls for an in vitro enzyme assay, histamine gave a reaction rate of less than $10 \%$ relative to putrescine, and spermine gave no detectable activity (Fig. 6). Thus, the polyamine-induced insolubilization of MGP at the root surface seemed to correlate closely with its substrate activity with DAO.

\section{Effect of $o$-phenanthroline and SHAM.}

The POD inhibitor salicylhydroxamate (SHAM; $2 \mathrm{mM}$ ) was tested to investigate the involvement of POD in catalyzing the $\mathrm{H}_{2} \mathrm{O}_{2}$-dependent putative cross-linking of MGP. When this inhibitor was added to the putrescine solution during the 5min pretreatment step, the exudation of MGP from root tips was completely restored (Fig. 7, lane A). Similarly, $o$ phenanthroline, a specific inhibitor of DAO, caused a partial restoration of MGP exudation from root tips (Fig. 7, lane B relative to lane $\mathrm{E}$ ). The combination of the two inhibitors induced even more MGP release (Fig. 7, lane C).

\section{MGP insolubilization by a partially purified extract of DAO.}

To confirm the involvement of DAO in the putative crosslinking of MGP at the root surface, a partially purified extract (PPE) containing an enriched activity of DAO was prepared from meristematic pea hooks. When PPE was added to the putrescine solution for the 5-min pretreatment step, MGP insolubilization was clearly more complete than in the case of a putrescine pretreatment alone (Fig. 8, lane C and B). Because the PPE fraction was also shown to possess a POD activity, we tested the effect of $o$-phenanthroline. In this case, the insolubilization of MGP was inhibited (Fig. 8, lane D). The same effect was observed with diethyl dithiocarbamate (5 $\mathrm{mM}$ ), another DAO inhibitor (Fig. 8, lane E).

\section{PSAO-1 expression is modulated along the nodulation process.}

The expression of PSAO-1 was followed in pea roots after inoculation with a compatible strain of $R$. leguminosarum bv. viciae. Total RNA was extracted from inoculated or uninoculated roots and treated with reverse transcriptase (RT). PSAO1 cDNA was amplified by RT-polymerase chain reaction (PCR) with gene-specific primers, and the abundance of ubiquitin was monitored as an internal standard (Fig. 9). In uninoculated roots, the expression of PSAO-1 declined slightly and progressively from 1 to 14 days post inoculation. On the other hand, the expression was up-regulated very

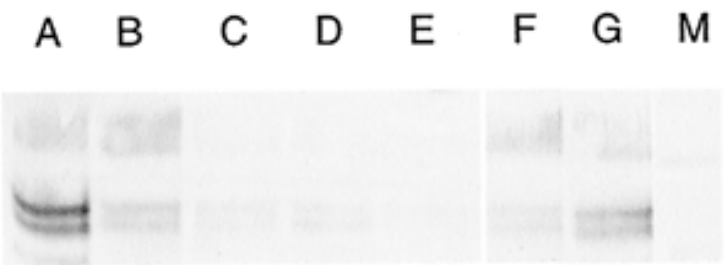

Fig. 4. Western blot (immunoblot) showing time course for reduced extractability of matrix glycoprotein (MGP) in relation to $\mathrm{H}_{2} \mathrm{O}_{2}$ concentration and length of pretreatment step. A, Control treatment in $50 \mathrm{mM}$ Tris- $\mathrm{HCl}$ buffer $\mathrm{pH}$ 7.4. B-E, Pretreatment with $5 \mathrm{mM} \mathrm{H}_{2} \mathrm{O}_{2}$. B, 2 min; C, $5 \mathrm{~min}$; D, $10 \mathrm{~min}$; E, $20 \mathrm{~min}$; F, 2 min of pretreatment with $2 \mathrm{mM}$ $\mathrm{H}_{2} \mathrm{O}_{2} ; \mathbf{G}, 2$ min of pretreatment with $0.5 \mathrm{mM} \mathrm{H}_{2} \mathrm{O}_{2} ; \mathbf{M}$, prestained molecular mass marker $(175 \mathrm{kDa})$. 
shortly after inoculation with the compatible bacteria. There was then a down-regulation of the expression followed by an up-regulation accompanying the full development of the nodule. These data correlated well with the results of in situ hybridization (Fig. 10), which showed strong expression of PSAO-1 transcript in the central infected tissues of the nodule, particularly in the zone of cell invasion. Furthermore, these observations confirmed the evidence from immunological and enzymological studies that DAO is present in infected tissues.

\section{DISCUSSION}

A characteristic of the plant defense response to microbial infection is the immobilization of wall proteins possibly through oxidative cross-linking and the consequent hardening of the plant cell wall that forms a barrier against invading pathogens (Bradley et al. 1992). In the Rhizobium-legume symbiosis, the situation is slightly different and there appears to be a fine balance between promotion and prevention of rhizobial colonization in host tissues. Even when the host is inoculated with a compatible strain of Rhizobium, a cellular defense reaction similar to the hypersensitive reaction is often observed (Vasse et al. 1993). Thus, it is important to establish what bacterial signals induce this localized defense response and what plant components are responsible for abortive infections.
In this study, we report that MGP, an extensin-like glycoprotein recognized by monoclonal antibody MAC265, undergoes insolubilization at the root tip surface by an $\mathrm{H}_{2} \mathrm{O}_{2}$ driven process. Previous evidence from immunogold localization studies (VandenBosch et al. 1989; Rae et al. 1992) has indicated that MGP is a prominent component of the infection thread that may regulate the ingress of invading bacteria inside host roots. However, biochemical isolation and analysis of MGP from the infection thread lumen is an almost impossible task. Given the small number and small dimensions of infection threads (Rae et al. 1992), it is extremely doubtful whether they represent even one thousandth part of the volume of a pea nodule. Furthermore, we suggest in this paper that MGP is only present in a soluble, extractable form in the region of the growing tip of infection threads and that else-

Table 1. Quantification of specific diamine oxidase (DAO) activity in different tissues of pea ${ }^{a}$

\begin{tabular}{lc}
\hline Tissue & Specific activity \\
\hline Epicotyls & $64.5 \pm 2.8$ \\
Uninoculated roots & $15.9 \pm 2.6$ \\
Wild-type-inoculated nodules & $24.6 \pm 2.1$ \\
\hline
\end{tabular}

${ }^{a}$ Values $\left(\delta A_{450}\right.$ per mg per $\left.10 \mathrm{~min}\right)$ are expressed as mean of five replicates $\pm \mathrm{SE}$.

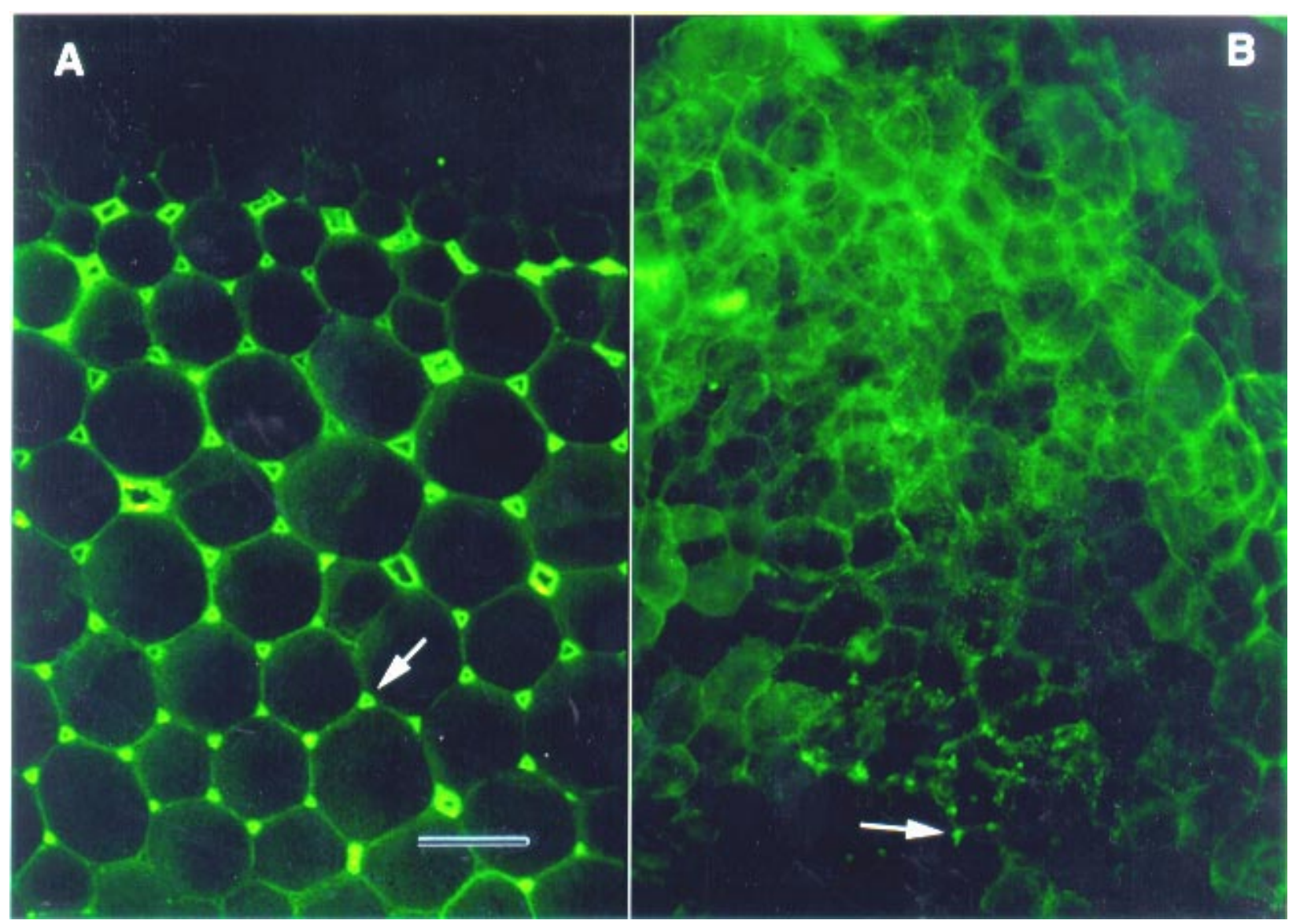

Fig. 5. Immunofluorescence labeling of diamine oxidase (DAO) with monoclonal antibody LM4. A, Transverse section of pea epicotyl with abundant occurrence of DAO antigen in regions of cell wall lining the intercellular spaces between cells (arrow). B, Transverse section near apex of a 2-week-old, wild-type-inoculated nodule. Cortical tissue is shown at top of micrograph; lower section (arrow) shows central invasion zone where antigen is associated with cells containing infection threads. Scale bar $=50 \mu \mathrm{m}$. 
where it is cross-linked into an insoluble and non-extractable form. In addition, it has been shown that MAC265 antigen is present in cell walls and intercellular spaces in infected and uninfected regions of the nodule (Fig. 5B and Rae et al. 1991) and these locations probably provide most of the MAC265 antigen present in nodule extracts. In view of these considerations, it would seem impossible to attempt a direct study of the physical and biochemical properties of MGP from the lumen of infection threads. Therefore, in the present study, we have made the assumption that the material that we have extracted from root tips is at least a close approximation to the cross-reacting antigen present in the lumen of infection threads.

We show that the loss of MGP extractability from root tips is rapid and dependent on $\mathrm{H}_{2} \mathrm{O}_{2}$ concentration. A similar in-

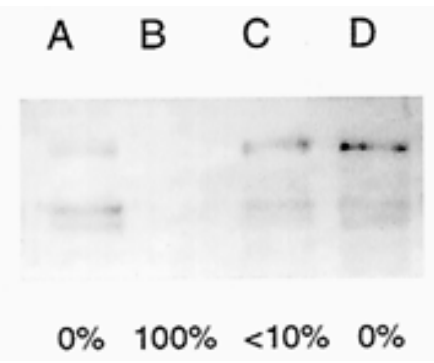

Fig. 6. Western blot (immunoblot) showing effect of different polyamines on the extractability of matrix glycoprotein (MGP). Root tips were pretreated for $5 \mathrm{~min}$ with $20 \mathrm{mM}$ polyamines in $50 \mathrm{mM}$ Tris$\mathrm{HCl}$ buffer $\mathrm{pH}$ 7.4. A, Control. B, Putrescine. C, Histamine. D, Spermine. Percentages represent relative activity for diamine oxidase in extracts from pea epicotyls, as quantified in vitro with each polyamine as substrate $($ putrescine $=100 \%$ )

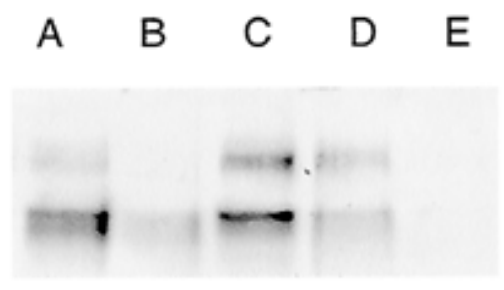

Fig. 7. Increased extractability of matrix glycoprotein (MGP) following pre-treatment with salicyl hydroxamate acid (SHAM) and $o$-phenanthroline. A, Pretreatment for 5 min with $20 \mathrm{mM}$ putrescine plus $2 \mathrm{mM}$ SHAM. B, $20 \mathrm{mM}$ putrescine plus $2 \mathrm{mM} o$-phenanthroline. C, $20 \mathrm{mM}$ putrescine plus $2 \mathrm{mM} o$-phenanthroline and $2 \mathrm{mM}$ SHAM. D, Control in $50 \mathrm{mM}$ Tris-HCl buffer $\mathrm{pH}$ 7.4. E, $20 \mathrm{mM}$ putrescine only.

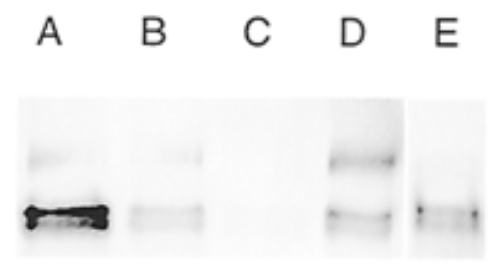

Fig. 8. Effect of diamine oxidase (DAO) as partially purified enzyme (PPE) from pea hypocotyls on the extractability of matrix glycoprotein (MGP). A, Control in $50 \mathrm{mM}$ Tris- $\mathrm{HCl}$ buffer $\mathrm{pH}$ 7.4. B, Pretreatment for 5 min with $20 \mu \mathrm{l}$ of PPE. C, As B plus $20 \mathrm{mM}$ putrescine. D, As C plus $2 \mathrm{mM} o$-phenanthroline. E, As C plus $5 \mathrm{mM}$ diethyl dithiocarbamate. solubilization of cell wall extensin was reported in elicited bean or soybean cells (Bradley et al. 1992; Wojtaszek et al. 1995). Enhanced POD activity that accompanies extensin insolubilization has been observed in elicited suspensioncultured tomato cells (Brownleader et al. 1997). In Medicago spp., a Rhizobium-induced POD has been cloned (Rip1) that shows localized activity prior to bacterial infection. $\mathrm{H}_{2} \mathrm{O}_{2}$ has also been shown to accumulate in roots of Medicago truncatula colonized by the arbuscular mycorrhizal fungus Glomus intraradices (Salzer et al. 1999).

We used enzyme inhibitors to analyze the process of MGP insolubilization. SHAM, a POD inhibitor, abolished MGP insolubilization. Because SHAM is an $\mathrm{H}_{2} \mathrm{O}_{2}$ scavenger, no distinction could be made between the inhibition of a possible POD-catalyzed $\mathrm{H}_{2} \mathrm{O}_{2}$ generation system and the inhibition of POD-catalyzed oxidative cross-linking.

Another possible source of $\mathrm{H}_{2} \mathrm{O}_{2}$ production in the lumen of infection threads and in intercellular spaces is through the activity of DAO. The use of $o$-phenanthroline, a DAO-specific inhibitor, showed a partial inhibition of MGP insolubilization. In addition, pea root tips incubated for 5 min with putrescine, the DAO substrate, showed no release of MGP and, by varying the substrate for DAO, we demonstrated that the
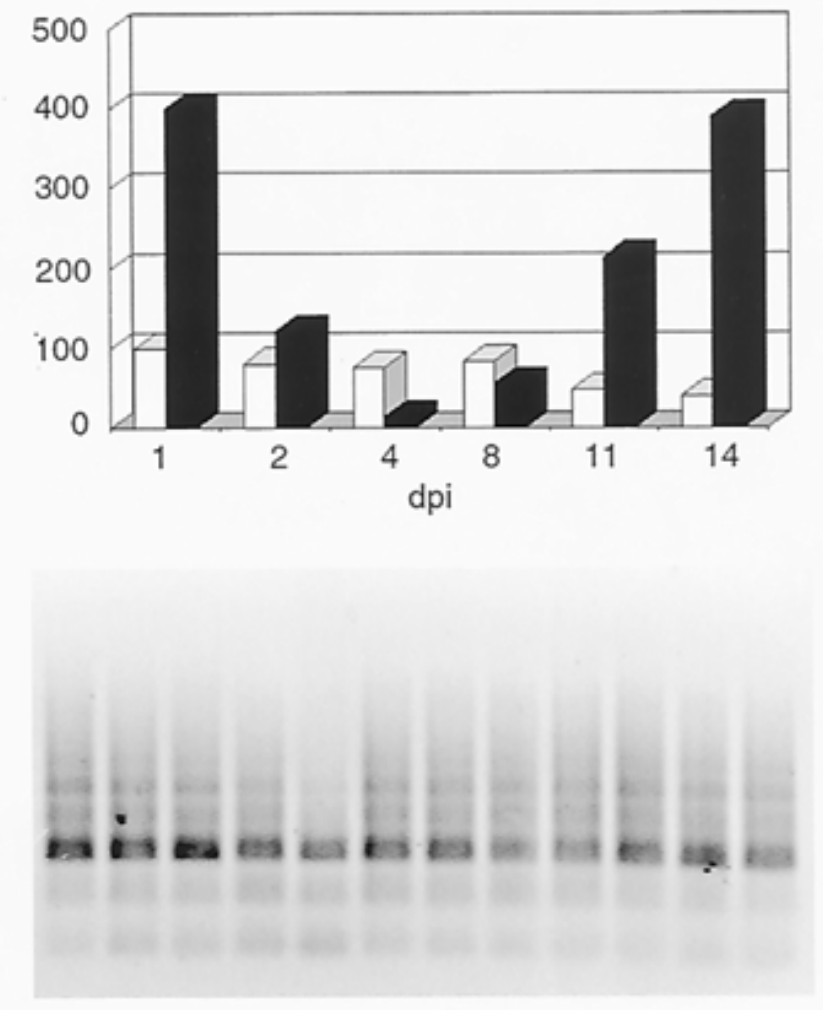

Fig. 9. Reverse transcriptase-polymerase chain reaction (RT-PCR) with diamine oxidase (DAO) gene-specific primers showing modulation of PSAO-1 transcription in pea roots inoculated with Rhizobium leguminosarum bv. viciae. Roots inoculated with wild-type strain 3841 were collected 1 to 14 days post inoculation (dpi). Corresponding noninoculated roots were harvested at the same time. PSAO-1 expression was determined by RT-PCR with total RNA. Relative RNA amounts were quantified with the molecular analyst software (Bio-Rad, Walford, UK) with values for the 1-day control set at $100 \%$. Lower panel, bands amplified with the ubiquitin primers show equalization of templates used for analysis. 
degree of MGP insolubilization was related to the activity of this enzyme.

We thus postulate that MGP insolubilization is the result of inter-protein cross-linking formed by a POD-catalyzed reaction, and that DAO activity is one of the possible sources of $\mathrm{H}_{2} \mathrm{O}_{2}$. Other possible sources of $\mathrm{H}_{2} \mathrm{O}_{2}$ include apoplastic oxalate oxidase (Brewin et al. 2000) and/or NADPH oxidase, which is located in the plasma membrane (Lamb and Dixon 1997). Assuming that insolubilization of MGP occurs within infection threads, it is possible that bacteria within the lumen could become entrapped by the progressive solidification of the matrix. This is consistent with the observation that extension growth is confined to the tip region of infection threads (Gage et al. 1996). In our model, continued extension of an infection thread would depend on the rate of secretion of fluid MGP at the growing tip being equal to or greater than the rate of peroxide-driven cross-linking. Factors that might increase the rate of infection thread abortion might be related to the local availability of peroxide (Fig. 11) and we suggest that this

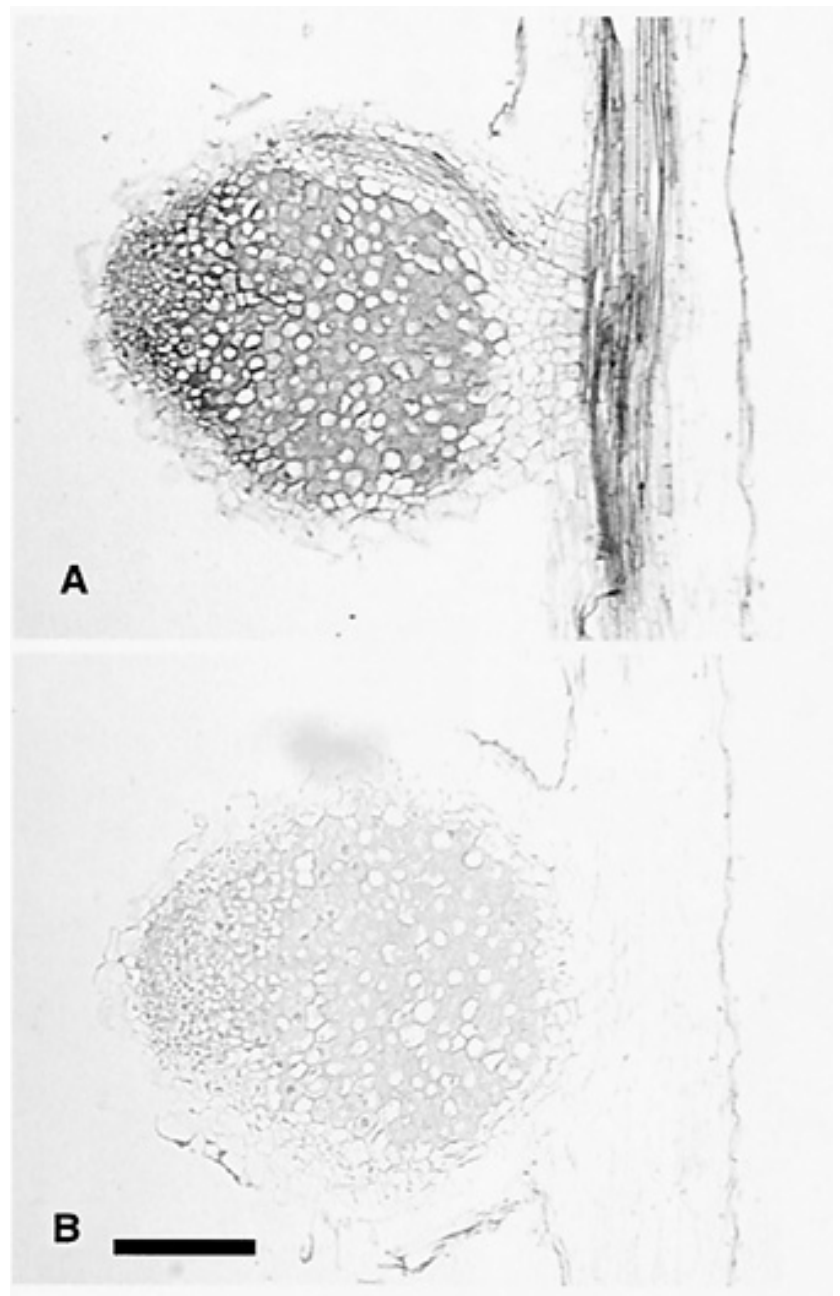

Fig. 10. In situ analysis of diamine oxidase (DAO) gene expression in pea nodule tissue. Adjacent median longitudinal sections were hybridized with riboprobes containing digoxygenin. A, Antisense DAO. B, Sense DAO (negative control). Scale bar $=0.5 \mathrm{~mm}$. Transcript expression (gray shading) was most intense in invasion zone, but was strong throughout central infected region. Transcript was also detected in root vasculature. might be the product of polyamine and DAO activity in the luminal matrix. (In addition, other sources of $\mathrm{H}_{2} \mathrm{O}_{2}$ might also be involved.) This model raises many interesting questions concerning how MGP might promote infection thread growth for compatible symbionts while serving as a barrier to cell and tissue colonization by inappropriate strains.

\section{MATERIALS AND METHODS}

\section{Plant culture and inoculation.}

Pisum sativum cv. Wisconsin Perfection was used. Pea seeds were surface sterilized with $70 \%$ (vol/vol) ethanol for 2 $\mathrm{min}$, then with a commercial bleach solution for $12 \mathrm{~min}$. After being rinsed with sterile water, they were germinated in a flask containing Fahreus plant (FP) medium for 7 days at $20^{\circ} \mathrm{C}$ in the dark. The R. leguminosarum bv. viciae strain 3841 was used in the described experiments and was cultured in tryptone yeast (TY) medium. The 7-day-old seedlings were inoculated with $100 \mu \mathrm{l}$ of a 1:100 dilution of a bacterial suspension with an $\mathrm{OD}_{600}$ of 0.1 (Wood et al. 1989). Seedlings of Vicia hirsuta were grown as previously described (Rae et al. 1991).

\section{Preparation of root exudate.}

Because MGP is exuded by the cells at the root tip, we used a bioassay with seedling roots to investigate the insolubilization of this glycoprotein. Sterilized pea seeds were allowed to germinate on FP agar plates for 4 days in the dark, yielding roots approximately $5 \mathrm{~cm}$ in length. The bioassay was performed in two steps (Fig. 2). In the first step, called pretreatment, the attached roots of six pea seedlings were transferred to a $0.5-\mathrm{ml}$ microcentrifuge tube containing a solution of 50 $\mathrm{mM}$ Tris-HCl, pH 7.4. Compounds to be tested such as $\mathrm{H}_{2} \mathrm{O}_{2}$ ( 1 to $5 \mathrm{mM})$, polyamines $(20 \mathrm{mM})$, and enzyme inhibitors $(2$ $\mathrm{mM}$ ) were included in this buffer to investigate their effect on MGP release from root tips. After soaking for $5 \mathrm{~min}$, the roots were washed twice in the Tris- $\mathrm{HCl}$ buffer and transferred to a microcentrifuge tube containing a solution of $50 \mathrm{mM}$ Tris$\mathrm{HCl}$, pH 7.4 supplemented with $10 \mathrm{mM}$ ascorbate, $10 \mathrm{mM}$ DTT (dithiothreitol), and $10 \mathrm{mM}$ EDTA. After extraction for $30 \mathrm{~min}$, the seedlings were removed. Protein content was de-

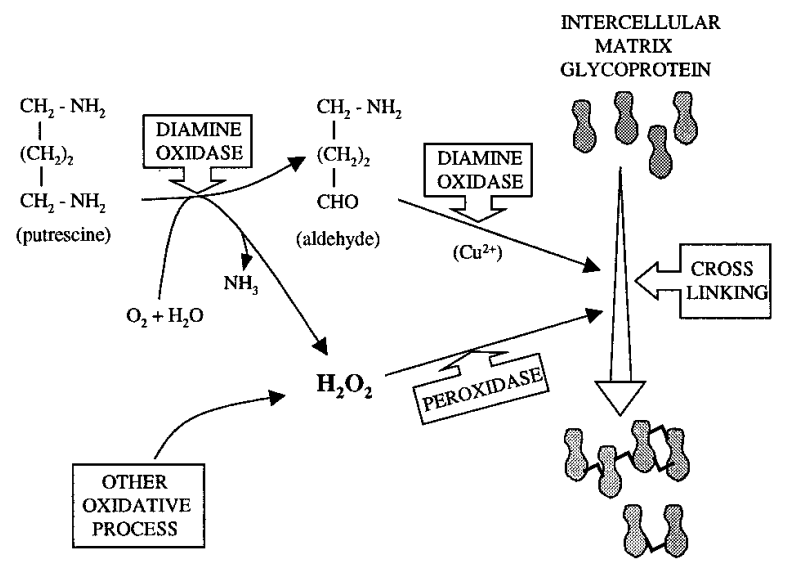

Fig. 11. Possible components involved in hardening of the extracellular matrix by peroxide-driven cross-linking of matrix glycoprotein (MGP), an extensin-type glycoprotein present in the lumen of infection threads. 
termined by the Bio-Rad assay system with bovine serum albumin (BSA) as a standard (Bio-Rad, Walford, UK). All samples were stored at $-20^{\circ} \mathrm{C}$ until further analysis.

\section{Immunolocalization of MGP and DAO.}

Rat monoclonal antibody LM4 was generated following immunization of rats with purified PSAO-1 protein obtained from D. M. Dooley (McGuirl et al. 1994). Etiolated pea epicotyls were hand sectioned and 2-week-old nodules were sectioned with a vibratome. Immunofluorescence procedures were as previously described (Smallwood et al. 1994). LM4 does not react with antigen after tissue fixation with either glutaraldehyde or formaldehyde and therefore it was necessary to use unfixed material for immunofluorescence studies.

Monoclonal antibody MAC265 (rat immunoglobulin class $\mathrm{IgG}$ ) was used to localize MGP at the surface of pea roots. Tissues were incubated overnight with MAC265 hybridoma culture supernatant (final dilution 1:10), and immunostained as for Western blotting (see below).

\section{Electrophoresis, Western blotting, and tissue blotting.}

SDS-PAGE on $10 \%$ (wt/vol) discontinuous gels was performed as described previously (Dahiya et al. 1997), with DTT $(0.1 \mathrm{mM})$ instead of $\beta$-mercaptoethanol. Proteins were transferred electrophoretically to nitrocellulose membrane (Schleicher and Schuell, Dassel, Germany), and the blots were blocked for $20 \mathrm{~min}$ with $1 \% \mathrm{BSA}(\mathrm{wt} / \mathrm{vol})$ in a solution containing Tris-buffered saline (TBS; $50 \mathrm{mM}$ Tris- $\mathrm{HCl}, 200 \mathrm{mM}$ $\mathrm{NaCl}$ ). Blots were then incubated for $2 \mathrm{~h}$ with the monoclonal antibody MAC265, with the hybridoma cell culture supernatant at a dilution of 1:200 in blocking solution. After being washed several times in TBS, the blots were incubated for $2 \mathrm{~h}$ with goat alkaline phosphatase-conjugated anti-rat IgG secondary antibody (Sigma, Poole, UK) diluted 1:5,000. After further washing, immunoadsorbed alkaline phosphatase was detected with a chromogenic substrate solution containing 5bromo, 4-chloroindolyl phosphate and nitroblue tetrazolium in Tris buffer $\left(100 \mathrm{mM}\right.$, pH 9.6, $\left.1 \mathrm{mM} \mathrm{MgCl}_{2}\right)$. All incubations were performed at room temperature.

Tissue blotting was used as a simple procedure to monitor the extractability of MGP from root tips. Seedling roots were bathed for $30 \mathrm{~min}$ in a solution of $50 \mathrm{mM}$ Tris- $\mathrm{HCl}, \mathrm{pH} 7.4$ supplemented with $10 \mathrm{mM}$ ascorbate, $10 \mathrm{mM}$ DTT, and 10 $\mathrm{mM}$ EDTA. After treatment for $30 \mathrm{~min}$, they were gently blotted with tissue paper and transferred for a few minutes to a sheet of nitrocellulose moistened with $50 \mathrm{mM}$ Tris- $\mathrm{HCl}, \mathrm{pH}$ 7.4, $10 \mathrm{mM}$ EDTA. The sheets were subsequently treated as for Western blots.

\section{Preparation of partially purified DAO.}

Partially purified DAO was prepared as described by Chiarello et al. (1996). Briefly, frozen tissue from the apical meristematic hook region of 10-day-old peas was homogenized in a chilled mortar with a $50 \mathrm{mM}$ Tris- $\mathrm{HCl}$ solution $(\mathrm{pH} 8.5)$ containing a cocktail of protease inhibitors (BoehringerMannheim, Mannheim, Germany). After centrifugation for 20 min at $12,000 \times g$, the supernatant was recovered and chilled. $\mathrm{HCl}(0.5 \mathrm{~N})$ was added drop by drop until $\mathrm{pH} 3.0$ was reached. After being stirred for $30 \mathrm{~min}$ at $4^{\circ} \mathrm{C}$, insoluble proteins were eliminated by centrifugation at $12,000 \times g$ for 20 min. The supernatant containing the active DAO fraction, termed partially purified enzymes (PPEs), was adjusted to $\mathrm{pH}$ 8.0 and frozen until required.

\section{DAO enzyme assay.}

DAO activity was determined by the following method with a microtiter plate with 96 wells. To $100 \mu$ of the protein solution to be tested, $100 \mu \mathrm{l}$ of the following assay mixture was added: putrescine $20 \mathrm{mM}, 3,3^{\prime}, 5,5^{\prime}$-tetramethyl benzidine 0.1 $\mathrm{mg} / \mathrm{ml}$, horseradish peroxidase (type I; Sigma) $0.3 \mathrm{mU}$ (in 0.1 $\mathrm{M}$ sodium acetate solution). After $10 \mathrm{~min}, 50 \mu \mathrm{l}$ of $\mathrm{H}_{2} \mathrm{SO}_{4}$ (1 M) was added to stop the reaction, and $A_{450}$ was estimated. The specific activity was calculated after subtraction of the value for $A_{450}$ obtained when $o$-phenanthroline was added to the protein sample.

\section{RT-PCR to quantify PSAO-1 expression.}

Total RNA was isolated according to the method of de Vries et al. (1982) and treated with DNase I (GibcoBRL, Paisley, UK). Each sample of cDNA was prepared from $3 \mu \mathrm{g}$ of total RNA in a volume of $20 \mu \mathrm{l}$ containing Tris- $\mathrm{HCl}(10 \mathrm{mM}, \mathrm{pH}$ $8.8), \mathrm{KCl}(50 \mathrm{mM}), \mathrm{MgCl}_{2}(5 \mathrm{mM})$, dNTPs $(1 \mathrm{mM}), 0.5 \mu \mathrm{g}$ of oligo-dT (T16), DTT (10 mM), and RT Superscript (200 U, GibcoBRL) for $1 \mathrm{~h}$ at $42^{\circ} \mathrm{C}$ followed by $15 \mathrm{~min}$ at $70^{\circ} \mathrm{C}$. RNA was removed by adding $1 \mathrm{U}$ of RNase $\mathrm{H}$ for $20 \mathrm{~min}$ at $37^{\circ} \mathrm{C}$. The RT samples were then diluted to $120 \mu$. The PCRs were performed with $5 \mu \mathrm{l}$ of the cDNA solution in Tris-HCl (10 $\mathrm{mM}, \mathrm{pH} 8.3), \mathrm{KCl}(50 \mathrm{mM}), \mathrm{MgCl}_{2}(2.5 \mathrm{mM})$, dNTPs (100 $\mu \mathrm{M}), 50 \mathrm{ng}$ of primers, and $1 \mathrm{U}$ Taq DNA polymerase (Perkin Elmer, Swindon, UK) in a total volume of $25 \mu \mathrm{l}$. The pea DAO cDNA (PSAO-1; Tipping and McPherson 1995) and ubiquitin cDNA were amplified by the following PCR program: $30 \mathrm{~s}$ at $94^{\circ} \mathrm{C}, 40 \mathrm{~s}$ at $60^{\circ} \mathrm{C}$, and $30 \mathrm{~s}$ at $72^{\circ} \mathrm{C}$. The primers were PSAO-1f (CTCGAGATGGCTTCCACCACCACC), PSAO-1r (CTCTTCTCCAAACCAGCC), ubi-f (ATGCAGA TC/TTTTGTGAAGAC) and ubi-r (ACCACCACGG/AA GACGGAG). Under the conditions used, the amplification of ubi and PSAO-1 mRNA was exponential up to 30 cycles. After 28 cycles, the amplified DNA samples $(5 \mu \mathrm{l})$ were separated on a $1.2 \%(\mathrm{wt} / \mathrm{vol})$ agarose gel containing $1 \times \mathrm{TBE}$ (Tris-borate-EDTA) and stained with ethidium bromide. The band intensity was quantified with the Molecular Analyst software (Bio-Rad). All experiments were performed at least in duplicate.

\section{In situ hybridization.}

A DNA fragment containing bases 74 to 996 from the cloned PsAO1 cDNA was used to generate the riboprobe for in situ hybridization, as described by Wisniewski et al. (1999). This primer was amplified by PCR with the reverse primer AAA GTT CAG AAA TGT AGCC and the forward primer ATG GCT TCC ACC ACC ACC and then cloned into pCR 2.1 (Invitrogen, Groningen, The Netherlands).

\section{ACKNOWLEDGMENTS}

We thank A. L. Rae for developing the cytological analysis of MGP release from root tips. J.-P. W. acknowledges receipt of an EU MarieCurie fellowship; E. A. R. and N. J. B. were supported by the GBBBSRC. PSAO-1 cDNA was the generous gift of $\mathrm{M}$. McPherson (University of Leeds) and LM4 antibody was produced with the assistance of S. Marcus. 


\section{LITERATURE CITED}

Angelini, R., Manes, F., and Federico, R. 1990. Spatial and functional correlation between diamine-oxidase and peroxidase-activities and their dependence upon deetiolation and wounding in chickpea stems. Planta 182:89-96.

Bradley, D. J., Kjellbom, P., and Lamb, C. J. 1992. Elicitor-induced and wound-induced oxidative cross-linking of a proline-rich plant-cell wall protein - a novel, rapid defense response. Cell 70:21-30.

Bradley, D. J., Wood, E. A., Larkins, A. P., Galfre, G., Butcher, G. W., and Brewin, N. J. 1988. Isolation of monoclonal antibodies reacting with peribacteroid membranes and other components of pea root nodules containing Rhizobium leguminosarum. Planta 173:149-160.

Brewin, N. J. 1991. Development of the legume root nodule. Annu. Rev. Cell. Biol. 7:191-226.

Brewin, N. J., Rathbun, E. A. and Wisniewski, J.-P. 2000. Structure and development of infection threads. Pages 381-382 in: Nitrogen Fixation: From Molecules to Crop Productivity. F. E. Pedrosa, M. Hungria, M. G. Yates, and W. E. Newton, eds. Kluwer Academic Publishers, Dordrecht, The Netherlands.

Brownleader, M. D., McNally, P. E., Davies, G. E. A., Trevan, M., and Dey, P. M. 1997. Elicitor-induced extensin insolubilization in suspension-cultured tomato cells. Phytochemistry 46:1-9.

Chiarello, M. D., Larre, C., Kedzior, Z. M., and Gueguen, J. 1996. Pea seedling extracts catalyze protein amine binding and protein crosslinking. 2. Contribution of diamine oxidase to these reactions. J. Agric. Food Chem. 44:3723-3726.

Cook, D., Dreyer, D., Bonnet, D., Howell, M., Nony, E., and VandenBosch, K. 1995. Transient induction of a peroxidase gene in Medicago truncatula precedes infection by Rhizobium meliloti. Plant Cell 7:43-55.

Dahiya, P., Kardailsky, I. V., and Brewin, N. J. 1997. Immunolocalization of PsNLEC-1, a lectin-like glycoprotein expressed in developing pea nodules. Plant Physiol. 115:1431-1442.

de Vries, S. C., Springer, J., and Wessels, J. H. G. 1982. Diversity of abundant mRNA sequences and patterns of protein synthesis in etiolated and greened pea seedlings. Planta 156:129-135.

Gage, D. J., Bobo, T., and Long, S. R. 1996. Use of green fluorescent protein to visualize the early events of symbiosis between Rhizobium meliloti and alfalfa (Medicago sativa). J. Bacteriol. 178:7159-7166.

Lamb, C. J., and Dixon, R. A. 1997. The oxidative burst in plant disease resistance. Annu. Rev. Plant Physiol. Plant Mol. Biol. 48:251-275.

Long, S. R., and Staskawicz, B. J. 1993. Prokaryotic plant parasites. Cell 73:921-935.

Maccarrone, M., Rossi, A., Avigliano, L., and Agro, A. F. 1991. Activity and expression of diamine oxidase in lentil seedlings under different growth-conditions. Plant Science 79:51-55.

Maccarrone, M., Veldink, G. A., Vliegenthart, J. F. G., and Agro, A. F. 1997. Ozone stress modulates amine oxidase and lipoxygenase expression in lentil (Lens culinaris) seedlings. FEBS Lett. 408:241-244.

McGuirl, M. A., McCahon, C. D., McKeown, K. A., and Dooley, D. M. 1994. Purification and characterization of pea seedling amine oxidase for crystallization studies. Plant Physiol. 106:1205-1211.

Medda, R., Padiglia, A., and Floris, G. 1995. Plant copper-amine oxidases. Phytochemistry 39:1-9.

Niehaus, K., Kapp, D., and Pühler, A. 1993. Plant defense and delayed infection of alfalfa pseudonodules induced by an exopolysaccharide (Eps-I)-deficient Rhizobium meliloti mutant. Planta 190:415-425.

Niehaus, K., Lagares, A., and Pühler, A. 1998. A Sinorhizobium meliloti lipopolysaccharide mutant induces effective nodules on the host plant
Medicago sativa (alfalfa) but fails to establish a symbiosis with Medicago truncatula. Mol. Plant-Microbe Interact. 11:906-914.

Otte, O., and Barz, W. 1996. The elicitor-induced oxidative burst in cultured chickpea cells drives the rapid insolubilization of two cell wall structural proteins. Planta 200:238-246.

Perotto, S., Brewin, N. J., and Kannenberg, E. L. 1994. Cytological evidence for a host defense response that reduces cell and tissue invasion in pea nodules by lipopolysaccharide-defective mutants of Rhizobium leguminosarum strain 3841. Mol. Plant-Microbe Interact. 7:99-112.

Rae, A. L., Bonfantefasolo, P., and Brewin, N. J. 1992. Structure and growth of infection threads in the legume symbiosis with Rhizobium leguminosarum. Plant J. 2:385-395.

Rae, A. L., Perotto, S., Knox, J. P., Kannenberg, E. L., and Brewin, N. J. 1991. Expression of extracellular glycoproteins in the uninfected cells of developing pea nodule tissue. Mol. Plant-Microbe Interact. 4:563570.

Salzer, P., Corbiere, H., and Boller, T. 1999. Hydrogen peroxide accumulation in Medicago truncatula roots colonized by the arbuscular mycorrhiza-forming fungus Glomus intraradices. Planta 208:319-325.

Salzwedel, J. L. and Dazzo, F. B. 1993. pSym nod gene influence on elicitation of peroxidase activity from white clover and pea roots by rhizobia and their cell-free supernatants. Mol. Plant-Microbe Interact. 6:127-134.

Smallwood, M., Beven, A., Donovan, N., Neill, S. J., Peart, J., Roberts, K., and Knox, J. P. 1994. Localization of cell wall proteins in relation to the developmental anatomy of the carrot root apex. Plant J. 5:237246.

Smith, T. A., and Barker, J. H. A. 1988. The di- and polyamine oxidase of plants. Pages 573-587 in: Progress in Polyamine Research. V. Zappia and A. E. Pegg, eds. Plenum Press, New York.

Tipping, A. J., and McPherson, M. J. 1995. Cloning and molecular analysis of the pea seedling copper amine oxidase. J. Biol. Chem. 270:16939-16946.

van Spronsen, P. C., Bakhuizen, R., van Brussel, A. A. N., and Kijne, J. W. 1994. Cell-wall degradation during infection thread formation by the root-nodule bacterium Rhizobium-leguminosarum is a 2-step process. Eur. J. Cell Biol. 64:88-94.

VandenBosch, K. A., Bradley, D. J., Knox, J. P., Perotto, S., Butcher, G W., and Brewin, N. J. 1989. Common components of the infection thread matrix and the intercellular space identified by immunocytochemical analysis of pea nodules and uninfected roots. EMBO J. 8: 335-341.

Vasse, J., Debilly, F., and Truchet, G. 1993. Abortion of infection during the Rhizobium meliloti-alfalfa symbiotic interaction is accompanied by a hypersensitive reaction. Plant J. 4:555-566.

Wisniewski, J. P., Gardner, C. D., and Brewin, N. J. 1999. Isolation of lipoxygenase cDNA clones from pea nodule mRNA. Plant Mol. Biol. 39:775-783.

Wojtaszek, P., Trethowan, J., and Bolwell, G. P. 1995. Specificity in the immobilization of cell-wall proteins in response to different elicitor molecules in suspension-cultured cells of French bean (Phaseolus vulgaris L.). Plant Mol. Biol. 28:1075-1087.

Wojtaszek, P., Trethowan, J., and Bolwell, G. P. 1997. Reconstitution in vitro of the components and conditions required for the oxidative cross-linking of extracellular proteins in French bean (Phaseolus vulgaris L.). FEBS Lett. 405:95-98.

Wood, E. A., Butcher, G. W., Brewin, N. J., and Kannenberg, E. L. 1989. Genetic derepression of a developmentally regulated lipopolysaccharide antigen from Rhizobium leguminosarum 3841. J. Bacteriol. 171: 4549-4555 